UDK 372.881.111.1

DOI https://doi.org/10.24919/2308-4863/43-1-30

Halyna BONDARENKO, orcid.org/0000-0001-8964-7270

PhD in Pedagogical Science, Lecturer, Senior Lecturer at the Department of Foreign Philology Municipal Establishment "Kharkiv Humanitarian-Pedagogical Academy" of Kharkiv Regional Council (Kharkiv, Ukraine) gallochka234@gmail.com

\title{
INNOVATIVE METHODS OF TEACHING FOREIGN LANGUAGES IN THE CONTEXT OF THE EDUCATIONAL PROCESS' HUMANISTIC ORIENTATION
}

The article reveals the vital problems of the use of innovative methods in teaching foreign languages in higher education and offers the theoretical discourse of this aspect. The main innovative methods of teaching foreign languages in higher education establishments have been observed and the main features of their implementation into educational process have been elicited in this article. The components of modern methods of teaching foreign languages have been analyzed and the main approaches to the mastering of foreign languages in the modern methodological literature have been observed. The article deals with the main objectives of modern methods of teaching foreign languages and observes the essence of these practical, educative, educational and developmental objectives. It has been stated that the distinctive tendency is being formed to strengthen the communicative orientation of the educational process. Thus, the communicability is named as the main methodological content of a modern foreign language lesson. The aims of innovative methods of teaching foreign languages, based on a humanistic approach have been clarified and the main principles of modern methods have been stated. The definition of the category of "interactive learning" has been made in the article. In addition, the basic principles of methods of cooperation in the system of interactive learning have been stated here. The main forms of pair and group work, which are used in communicative method have been elicited. The role of communicability in the process of globalization and in the growing importance of cultural exchanges, integration into Europe, commitment to world values has been clarified. The leading motives for learning English as a professional discipline by students of higher education, their motivational sphere, developing ways and methods of its correction have been outlined in the article.

Key words: innovative methods of teaching, communicability, interactive learning, teaching foreign language, humanistic orientation.

Галина БОНДАРЕНКО,

orcid.org/0000-0001-8964-7270

кандидат педагогічних наук, викладач, старший викладач кафедри іноземних мов

Комунального закладу «Харківська гуманітарно-педагогічна академія» Харківської обласної ради (Харків, Украӥна) gallochka234@gmail.com

\section{ІННОВАЦЙНН МЕТОДИ ВИКЛАДАННЯ ІНОЗЕМНИХ МОВ У КОНТЕКСТІ ГУМАНІСТИЧНОЇ СПРЯМОВАНОСТІ НАВЧАЛЬНОГО ПРОЦЕСУ}

\footnotetext{
У статті теоретично обтрунтовано проблеми використання інновачійних методів викладання іноземної мови у вищій освіті. Виокремлено основні інновачійні методи викладання іноземних мов у закладах вищої освіти та основні особливості застосування иих методів у навчальному прочесі.

Проаналізовано складники сучасної методики навчання іноземних мов та розглянуто основні підходи до оволодіння іноземними мовами в сучасній методичній літературі. У статті розглянуто основні завдання сучасноі методики навчання іноземних мов та сутність цих практичних, виховних, навчальних та розвивальних завдань. Констатовано, щзо формується відмінна тенденція до посилення комунікативної спрямованості навчального проиесу. Таким чином, комунікабельність названа основним методичним змістом сучасного заняття з іноземної мови. 3'ясовано иілі інноваційної методики навчання іноземних мов, заснованої на гуманістичному підході, та сформульовано основні принциипи сучасної методики. У статті дано визначення категорії «інтерактивне навчання». Крім того, викладено основні принциии методів співпраці в системі інтерактивного навчання. Виявлено основні форми парної та групової роботи, які використовуються в комунікативному методі. 3 'ясовано роль комунікабельності в процесі глобалізації та зростанні значення культурних обмінів, інтеграциї в Свропу, відповідності світовим культурним та моральним иінностям, а також важливість досконалого володіння мовою та професійної майстерності викладача для ефективного навчання іноземних мов у процесі організації навчальної діяльності студентів $з$ оволодіння іншомовною діяльністю. У статті окреслено провідні мотиви вивчення англійської мови як професійної дисиипліни студентами вищих навчальних закладів, їх мотивачійну сферу, розвиток шляхів і методів ії корекції.

Ключові слова: інноваційні методи викладання, комунікативність, інтерактивне навчання, викладання іноземних мов, гуманістична спрямованість.
} 
Formulation of the problem. An important component of a developing democratic society in Ukraine is the focus on the humanistic values of world culture. The public, politicians, scientists and educators are increasingly aware of the need to build a united Europe, in particular a scientific and educational space without borders. Particular attention is paid to higher education, universities, their intellectual potential, which is constantly strengthened and used in the European integration process, to disseminate the necessary knowledge in order to understand common values (Kriuchkov, 2004: 5).

The state is in need of highly qualified specialists with knowledge of foreign languages, professionals who are able to absorb everything new and progressive, ready to generate and implement fresh original ideas, as well as to participate profitably in international cooperation and form a new attitude to Ukraine in Europe and the world.

The currentstate of Ukraine's international relations in various spheres of life, its entry into the European and world space, new political, socio-economic and cultural realities require certain transformations in the field of education as an important state institution, including the field of foreign languages. Today, as never before, the status of a foreign language tends to grow steadily. Among the world community, it is increasingly becoming a means of intercultural communication. All this leads to the definition of the main innovative strategic directions for improving the goals, content, methods, techniques and tools of foreign language teaching.

Research analysis has shown that in the scientific literature, some aspects of educational innovation are covered in the following areas: innovative pedagogical technologies: M. Zhaldak, I. Nosachenko, V. Oliynyk, A. Pidlasy, I. Pidlasy, S. Sysoeva; theoretical issues of pedagogical innovation: L. Burkova, L. Vashchenko, I. Dychkivska, O. Popova; examination, evaluation and selection of educational innovations, monitoring of innovative educational processes, innovative experiment: K. Bakhanov, L. Burkova, Y. Gilbukh, L. Danylenko.

The objective of the article is to represent the main innovative methods of teaching foreign language and elicit the main features of their implementation into educational process.

Presenting the main material. Effective teaching of foreign languages requires from the teacher a perfect command of the language, as well as professional skills in organizing the educational activities of students to master foreign language activities. The learning process is realized through the efforts of two of its participants - a teacher and a student. Regarding the management of this process, defining its strategy and tactics, the main role belongs to the teacher.

The specificity of teaching a foreign language, in contrast to other subjects, is that the teacher needs to form the new student's stereotype of speech communication in addition to the native language, which has already existed. Thus, the basis of theoretical knowledge of modern methods of teaching foreign languages consists of the following components:

- general theoretical knowledge of basic methodological concepts (methodology as a science is related to other sciences and the achievements of foreign language teaching methods reflect the achievements in the field of linguistics, psychology, sociology, etc.).

- issues of organization the teaching foreign phonetics, vocabulary, grammar and types of speech activity (speaking, listening, reading, writing); questions of the organization of training include consideration of methodical concepts, explanation of language material features, stages of training, methods of training concerning mastering of speech skills.

- the problem of monitoring the foreign language teaching; monitoring of functions, objects of monitoring and criteria for assessing the level of proficiency in foreign language speech activities.

The success of learning a foreign language largely depends on the chosen approach to learning. The term "approach" means a general initial conceptual position that is crucial in considering and defining other subordinate conceptual positions, in other words, "approach" means a learning strategy.

The following approaches have been allocated in the modern methodological literature:

- Behavioral approach that defines mastering a foreign language as the formation of responsive reactions to foreign language incentives.

- Intuitive-conscious approach that involves mastering a foreign language in modelling in an intensive mode, followed by awareness of their importance.

- Conscious cognitive approach that directs the student's activities to master the rules of using lexical and grammatical models, on the basis of which the conscious construction of statements has been made.

- Communicative active approach that involves an organic combination of conscious and subconscious components in the process of learning a foreign language, i.e. learning the rules of operation the foreign language models occurs simultaneously with the mastering of their communicative-speech function. The communicative-activity approach was determined as a result of methodical comprehension 
of scientific achievements in the field of linguistics (theory of communicative linguistics) and psychology (theory of activity) in the works of Y. Pasov, S. Shatilov, G. Rogova and others.

The communicative active approach to teaching foreign languages that is adopted in modern methodology, determines the selection of objectives, principles, content, methods, techniques and means of teaching.

The modern methods of teaching foreign languages put forward the following objectives: practical, educational, educative and developmental. The practical objective is leading, this is due to the fact that learning a foreign language is learning the ability to carry out foreign language communication.

The practical objective involves the practical mastery of a foreign language, i.e. mastering all language tools for foreign language interpersonal communication in the main types of speech activities: listening, speaking, reading and writing. Students must master the program language material as a means of designing or understanding the statements in the process of communication for their correct use in appropriate speech situations, be able to select independently those language and speech tools that are optimal for the implementation of communicative intent.

The educational objective involves enriching the spiritual world of the individual, obtaining and expanding knowledge about the culture of the country, which language is being studied and also the native country, namely history, literature, painting, music, customs, traditions, etc.; about the structure of the foreign language being studied, its system, character, features.

The educative objective lays in educating a person of high moral quality with the help of foreign language, in forming positive character traits. Education of students in the process of learning a foreign language is provided by:

- selection of educational material (texts, situations), which reflects universal moral values, such as kindness, humanity, patriotism, mutual respect and mutual understanding between people, etc.;

- application of problem tasks that are needed to be solved in the learning process;

- expressing their feelings, views, critical assessment and their own opinion about various events, relationships, facts, which are reflected in the informative educational material.

The developmental objective is realized in the process of learning a foreign language in two directions:

- the development of individual psychological characteristics of the student's personality, which affect the success of mastering a foreign language speech activity. These are phonetic and intonation hearing, flexibility of the articulatory apparatus, the amount of operative and long-term auditory and visual memory, speech guessing, etc.;

- development of special learning skills, such as the ability to work independently with a variety of learning tools, the ability to work in different modes of learning and control, the ability to think logically; general cultural skills to communicate with other people.

Learning objectives are closely related to the content of learning. In modern methodology of teaching foreign languages, the problem of content is solved from the standpoint of methodology as a science and its interrelations with related sciences and is also based on the position of communicative active approach to learning.

The content of foreign language teaching should ensure the achievement of learning objectives, its structure may consist of the following groups of components

- Areas of communication, topics, situations.

- Language and speech training material.

- Knowledge, skills and abilities of speech.

According to the National Doctrine of Education Development, the main directions of updating the content of higher education are: personal orientation of the educational system, priority of universal and national values, ensuring the quality of education based on the latest achievements of science, culture and social practice (Kovalenko, 2003: 8).

A distinctive tendency is being formed to strengthen the communicative orientation of the educational process, its approximation to the real process of communication. Thus, the methodological content of a modern foreign language lesson should be communicability.

In the process oflearningbycommunicativemethod, students acquire communicative competence - the ability to use the language depending on the specific situation. They learn to communicate in the process of communication itself. Accordingly, all exercises and tasks should be communicatively justified by information deficit, choice and reaction (information gap, choice, feedback). The most important characteristic of the communicative approach is the use of authentic materials, i.e. those that are actually used by native speakers. Students` speech interaction sometimes, though not always, takes place with the participation of the teacher in various forms: pairs, triads, small groups, with the whole group. From the very beginning, students master all four types of speech activity at the supra-phrase and text levels with limited use of the native language. The object 
of evaluation is not only the correctness, but also the speed of speaking and reading.

To achieve communicative competence - i.e. communicative skills that are formed on the basis of language knowledge, skills and abilities - a foreign language teacher uses the latest teaching methods that combine communicative and cognitive objectives. Innovative methods of teaching foreign languages, based on a humanistic approach, are aimed at the development and self-improvement of the individual, the disclosure of his/her reserve capabilities and creative potential, create the conditions for effective improvement of the educational process in higher education. The main principles of modern methods are: the movement from the whole to the single, learner-centered lessons, purposefulness and content of classes, their focus on achieving social interaction in the presence of the teacher's faith in the success of their students, language integration and language acquisition using knowledge from other fields of science. There are different variants of this direction in modern methodology, which have different names - "Whole Language Content Approach", "Cognitive Approach", "Content-Based ESL Program", "Cognitive Academic Language Approach", "Co-operative Learning", "Interactive training" (Stern, 1983: 284).

The interactive method provides an opportunity to solve communicative - cognitive tasks by means of foreign language communication. The category of "interactive learning" can be defined as: a) the interaction of teacher and student in the communicative process; b) training to solve linguistic and communicative problems. Interactive activities include the organization and development of dialogical speech, aimed at mutual understanding, interaction, solving problems important to each of the participants in the learning process.

In the system of interactive learning there are the following basic principles of methods of cooperation:

1) positive interdependence - the group succeeds in terms of great performing of each student;

2) individual responsibility - working in a group, each student performs his task, different from others;

3) equal participation - each student is given the same amount of time to have a conversation or complete a task;

4) simultaneous interaction - when all students are involved in the work (Burns, 2012: 208).

In the process of communication students learn:

1. to solve complex problems based on the analysis of circumstances and relevant information;

2. to express alternative opinions;

3. to make informed decisions;
4. to communicate with different people;

5. to take part in discussions.

Modern communicative methods offer a wide introduction of active non-standard methods and forms of work into the educational process for better conscious assimilation of the data. In practice, such forms of work as individual, pair, group and team work have been shown to be quite effective.

The most famous forms of pair and group work are:

1. inner (outer) circles;

2. brain storm;

3. jigsaw reading;

4. exchange of thoughts (think-pair-share);

5. pair-interviews and others (Thornbury, 2017: 82).

For example, jigsaw reading means an activity that involves dividing a text into parts or using different texts on the same subject. Excerpts of the text are given to students for reading with further discussion in order to identify the content of the whole text or to express different points of view on what has been read.

It should be noted that all the above forms of interactive learning are effective if the problem was previously discussed in class and students have some experience and ideas gained earlier in the learning process.

The teacher should also take into account the fact that the topics for discussion should not be limited. One of the features of interactive forms of learning is that they motivate the student not only to express their own point of view, but also to change it under the reasoned influence of partners in the communication process.

Among the identified benefits of interactive learning are the following:

1) establishing a friendly atmosphere and relationships between participants;

2) students have the opportunity to be more independent and confident;

3) the teacher encourages students to cooperate, cheers them up, they are not afraid to make mistakes;

4) students have the opportunity to overcome the fear of the language barrier;

5) the teacher does not dominate;

6) each student is involved in the work; has a specific task;

7) weak students can get help from stronger ones;

8) students can use their knowledge and experience gained earlier.

Thus, the latest methods of teaching foreign languages contribute to a one-time solution to problems of communicative, cognitive and educational nature: to develop communicative skills, establish emotional contact with students, teach them to work in a team, take into account the thoughts and statements of others. 
As previous experience shows, the use of these teaching methods relieves students' nervous tension, changes the forms of activity, draws attention to the main issues of the lesson.

Thus, the study and practical application of innovative methodological approaches provide an opportunity for foreign language teachers to implement and improve new methods of work, increase the efficiency of the educational process and the level of knowledge of students.

The new vision of education aims to create a motivational environment for students in the process of learning foreign languages. The principle of functional approach in the process of learning foreign languages is basic. In this approach, communicability, as the main function of language, is more fully performed, both in linguistic and conceptual-thematic direction. The growing importance of cultural exchanges, integration into Europe, commitment to world values, the process of globalization have increased opportunities for contact with native speakers. Thus, the study of a foreign language acquires practical significance, and the communicative function of language plays a major role in the process of expressing feelings, judgments and assimilation of information, knowledge, presented in any form.

When using the language, one goal dominates: to receive information, to ask information, to motivate for the action, to express feelings, etc. Such materialization of communicative acts can take various forms of expression, from the simplest to the most complex ones.

Analysis of the practice of teaching English in higher education showed that textbooks and methodological materials which are used in the learning process do not sufficiently take into account the role and importance of the motivational sphere of students, the dynamics of meaningful learning motives in studying, the measure and nature of motivational readiness to the acquisition of knowledge, to master the methods of such assimilation with specific methodological techniques.
Therefore, the urgent problem is to study the motivational sphere of students, developing ways and methods of its correction and development.

The leading motives for learning English as a professional discipline by students of higher education are the motives of professional achievement, communicative, cognitive and external motives. The means of their formation is the method of teaching and the content of English as a subject.

Specific motives for learning English are communicative motives. The most important condition for their formation and development is to give a communicative character to the whole course of teaching English.

The innovative status of a foreign language teacher in the system of normative and developmental learning, namely the active regulator of the teaching process, gives him freedom of action in methodological and didactic activities and in all his initiatives. All didactic initiatives are concentrated around the student's personality. Democratization of bilateral relations "student-teacher" aims not only the freedom of decisions on the part of students, but also the responsibility of the teacher in the process of testing the knowledge acquired by the student. The teacher must create a motivational environment for students, adequate for learning foreign languages.

Conclusion. Thus, we can conclude that the effectiveness of communicative foreign language teaching will depend on the desire and ability of teachers to use the positive experience of domestic and foreign scholars and practitioners on the humanistic approach to learning, understanding the need to abandon authoritarian and scholastic methods. Methods of teaching foreign languages, based on a humanistic approach, help to reveal the creative potential of students and contribute to the development and self-improvement of the educational and communicative process, the formation of future conscious patriots of their country, tolerant citizens. And this ensures Ukraine's entry into the European educational space.

\section{BIBLIOGRAPHY}

1. Інноваційні технології у вивченні англійської мови / упоряд.: Т. Михайленко. Київ : Шкільний Світ, 2008.128 с.

2. Крючков Г. Болонський процес як гармонізація Свропейської системи вищої освіти. Педагогічна преса. Іноземні мови в навчальних закладах. 2004. № 1. С. 4-8.

3. Коваленко О. Концептуальні зміни у викладанні іноземних мов у контексті трансформації іншомовної освіти. Педагогічна преса. Іноземні мови в навчальних закладах. 2004. № 1. С. 4-10.

4. Burns, A. The Cambridge Guide to Pedagogy and Practice in Second Language Teaching. Cambridge: Cambridge University Press. 2012. 314 p.

5. Stern, H.H. Fundamental Concepts of Language Teaching. Oxford : Oxford University Press. 1983. 582 p.

6. Thornbury S. Scott Thornbury's 30 Language Teaching Methods. Cambridge : Cambridge University Press. 2017. 140 p. 


\section{REFERENCES}

1. Innovatsiini tekhnolohii u vyvchenni anhliiskoi movy [Innovative technologies of the English language learning]/ uporiad.: T. Mykhailenko. Kyiv : School World, 2008. 128 p. [in Ukrainian].

2. Kriuchkov H. Bolonskyi protses yak harmonizatsiia Yevropeiskoi systemy vyshchoi osvity [The Bologna process as the harmonization of the European system of higher education]. Pedagogical press. Foreign languages in educational establishments. 2004. № 1. C. 4-8 [in Ukrainian].

3. Kovalenko O. Kontseptualni zminy u vykladanni inozemnykh mov u konteksti transformatsii inshomovnoi osvity. [Concept changes in the foreign language teaching in the context of the foreign language education transformation]. Pedagogical press. Foreign languages in educational establishments. 2004. № 1. C. 4-10 [in Ukrainian].

4. Burns, A. The Cambridge Guide to Pedagogy and Practice in Second Language Teaching. Cambridge: Cambridge University Press. 2012.314 p.

5. Stern, H.H. Fundamental Concepts of Language Teaching. Oxford : Oxford University Press. 1983. 582 p.

6. Thornbury S. Scott Thornbury's 30 Language Teaching Methods. Cambridge : Cambridge University Press. 2017. 140 p. 